UDC 378.147

Olena Kononova $^{1}$, Alona Yurzhenko ${ }^{2}$

${ }^{1}$ Maritime college of Kherson State Maritime Academy, Kherson, Ukraine

${ }^{2}$ Kherson State Maritime Academy, Kherson, Ukraine

\title{
ENGAGING FUTURE SHIP ENGINEERS IN DISTANCE STEM EDUCATION
}

\section{DOI:10.14308/ite000729}

The research summarizes the modern approaches to STEM education for future ship engineers: the problem-based learning activities, not standard or typical designs and problems, the integration of STEM subjects, the introduction of innovation to teaching methods in relation to each subject, the multidisciplinary approach to STEM education that implies the integrative environment for teaching STEM subjects. It is highlighted that in the era of industrialization, literacy and work skills were important, but in the post-industrial era, the technological aspects of youth development have come to the fore. It has been also determined that awakening a creative approach, interest in a comprehensive perception of the subject of study, critical thinking, STEAM teachers give students more than just knowledge - they also give them skills, a taste for knowledge and work, a desire to immerse themselves in self-development, to love the learning process itself. The study presents the content-related and structural characteristics of STEM targets, approximate educational outcomes, content, final assessment, focus areas (problem solving situation), technological curriculum design methods provided by STEM techniques. The research describes the hands-on experience of involving teachers in creating STEM projects for ship engineers in distance STEM education. It is concluded that it is impossible to overestimate the prospect of using information technology in the implementation of STEM programs. Another conclusion is that graduates of educational institutions that actively use information technology in medicine, construction, chemistry, physics, biotechnology and other fields of science are becoming more and more in demand.

Key words: STEM education, ship engineers, MOODLE, creative task solving, information technology.

\section{Introduction}

Education is a mirror of the future of the country. The function of modern education is to prepare a comprehensively developed graduate who owns information technologies and knowledge in several areas that are in demand in modern society and who are able to think critically and build a successful career in conditions of a growing pace of technical progress. A well-thought-out educational system will allow the generation of creative thinkers capable of adaptation, in the changing conditions of modernity, which will help effectively compete in the global market. Depending on what the state sees its strengths, growth areas, it adjusts the national educational program, right down to the very foundations of the education system. In the era of industrialization, literacy and work skills were important. In the post-industrial era, the technological aspects of youth development have come to the fore.

The result was the digital revolution - with the Internet, the widespread use of computers, information technology. But over time, it turned out that the quality of the product, its productivity, manufacturability is no longer as important as the ease of use.

Different experts interpret the essence of STEM and STEAM concepts in their own way. But many of the principles of these educational systems have become generally accepted.

The word "stem" means "trunk" or "base": the four disciplines of STEM are considered the main in innovation, which many modern economies emphasize. In the educational process based on 
the STEM and STEAM concepts, these four subjects are integrated into the curriculum and their elements are presented in the study of almost all other disciplines, where possible. The main goal of STEM / STEAM education is the development of creative thinking, the skills of using an engineering approach for solving real problems, understanding the importance of design, and understanding the role of technologies in solving them. Under "Arts" in a concept, they often understand the development of creative perception, teaching the basics of modeling and art and technical design, which allows not only to make the educational process more diverse and richer, but also to further encourage students to solve tasks creatively and understand the principles of aesthetics.

In general, if we evaluate the prospects of these two concepts - the "pure" STEM and STEAM with a creative component, then the first of them was more in demand at the end of the last century. At the same time, STEAM can adequately and efficiently respond to the challenges of not only today, but also the future. Here we are talking about the fact that a significant part of the work processes is now amenable to automation, and in the future, as analysts predict, more and more professions will fall into the risk zone, disappearing one after another - they will be replaced by artificial intelligence. Understanding human needs and creatively rethinking the issues we face is the prerogative of specialists who are familiar with the humanitarian aspects of personality development, creativity, art, philosophy.

It is important to note that the idea of using diverse development methods in the field of education is not some know-how. For example, there is the SEL concept, which implies the development of social and emotional skills in children, on which they rely on the education of "people of the future". Or, a method of phenomenally-oriented teaching and teaching PBL, similar to STEM in the sense that both here and there, attempts are made to combine different disciplines when studying or developing a topic.

The aforementioned PBL methodology and the STEM concept in many respects provide for the reinforcement of technical disciplines in the humanities. Therefore, a logical step was the attempt to "legitimize" such a union, to connect the creative aspect of personality development to the purely technical concept of STEM. So, there were systems where, along with science, technology, engineering and mathematics, there are Art - this is the concept of STEAM, Music STEMM, Reading with Art - STREAM. The STEAM technique as a full-fledged, held, and self-sufficient phenomenon was most widely used.

It is worth noting that such an integrated approach, when technical disciplines are combined with creativity, helps to arouse in the student an interest in learning. STEAM allows you to connect to dry numbers and facts meanings, without which it is difficult for a person to perceive for a long time information of a different level of abstraction, whether it can be mathematical, physical or chemical formulas. Awakening a creative approach, interest in a comprehensive perception of the subject of study, critical thinking, STEAM teachers give students more than just knowledge - they also give them skills, a taste for knowledge and work, a desire to immerse themselves in self-development, to love the learning process itself.

\section{Analysis of recent research and publications}

Ukrainian scientist Denderenko O. O. investigated STEM education as one of the ways to involve cadets of ship engineering department to solve applied problems. He proved that STEM education in future ship engineers' training has great pedagogical effect. By the way, in 2020 Ukrainian government has accepted strategy on STEM until 2027 which is focused mainly on competencies formation. But unfortunately STEM education of ship engineers wasn't investigated as broadly as in other foreign countries. From the investigations found by us we can conclude that STEM education in Ukraine is located at the initial stage. In the United States, for example, STEM education at the state level was supported by the America COMPETES Act or The America Creating Opportunities to Meaningfully Promote Excellence in Technology, Education and Science 
Act, Representative Bart Gordon [1-2]. This law focused on STEM education of teachers, applied bachelor programs and the creation of innovative teaching methods. In 2010, its action was extended, thus confirming the course on STEM education at the state level. Since 2013, the United States has been implementing the Federal 5-year strategic plan for STEM education (2013-2018).

The goal of this plan is to help prepare the domestic workforce to maintain the status of the United States as a leader in innovation, to raise the rating of the United States in school education in STEM subjects [3-5].

Today, when creating any product, non-material aspects are priority at the intersection of ergonomics and philosophy. This is primarily a human need, such as the pleasure of use. On this, in particular, was built the success of Apple, which put user satisfaction first and broke the bank. Accordingly, in education, such moments as teaching technical sciences, mathematics, engineering, by themselves, ceased to be important. Their importance grows as one understands the role of each discipline in the process of creating a ready-made solution, behind which there is a person who uses it. So, in an attempt to find the ideal tool for conveying an understanding of the complex aspect of "man in the world", the STEM concept was born in the USA. According to this concept, during the training, specialists must learn to clearly understand what place in the world each specific product will take, each future development.

Such an integrated approach to traditional subjects allows students to evaluate how relevant their calculations are, to understand what place in the world is occupied by the issues they solve. And STEM is not only suitable for training technical specialists. Moreover, this system is applicable not only in universities - already today it is successfully used even in schools and preschool institutions.

The STEM methodology is supported by scientists who have proven the advantage of interactive learning in the form of studies compared to the traditional model of teacher-student knowledge transfer.

American students and schoolchildren, in whose teaching they use the STEM concept, master disciplines in relation to the real world experience. This does not mean that they study only those subjects whose names created the acronym STEM. No, American schools have shifted the emphasis in curricula to areas that have not been given enough attention; thus, the educational process was brought closer to the requirements of the modern economy, including the ability to quickly market innovative and competitive products. By betting on innovation, the Americans managed to maintain their leadership in the global economy: the USA is developing technologies and designs for products, which account for most of the added value, while production is established in Asian countries.

Today, the assembly of the finished product is often much less profitable than the implementation of the intellectual part of the project - at the level of ideas, drawings, inventions and patents. And the United States, realizing this, remains the strongest economy, which continues to largely set the pace of innovation in the world, leading in different ratings.

The United States managed to find a reasonable compromise between attracting scientists from all over the world to research and development, developing high technologies, creating the added value mentioned above, and, of course, developing higher education (considering the STEM concept).

Americans, trendsetters at STEAM, are embracing the concept everywhere. In the USA, National Day STEM and STEAM was even established. Accordingly, the number of educational institutions that adhere to the STEM and STEAM methodologies is significantly larger here than in other countries. The STEAM adept at the time was the Rhode Island School of Design (RISD) here in the USA. The popular college, deservedly considered one of the best arts and design schools in the world, comprehensively supports the implementation of the concept in educational institutions at all levels and claims that the STEAM approach will help to develop an educational model that is more suitable for training personnel of the 21 st century. 
The system promotes the development of important properties and skills:

-comprehensive understanding of the problem,

-creative thinking,

-engineering approach,

-critical thinking,

-understanding and applying the scientific method,

-understanding the basics of design.

Sherman M. finds that during the lesson, students get to know the information they will use in future. Being divided into several groups they were given different situations to solve. Creative/ critical thinking would help them while solving the problem [2].

The list of the subjects STEM helps the students with can be seen in figure 1 [6-8].

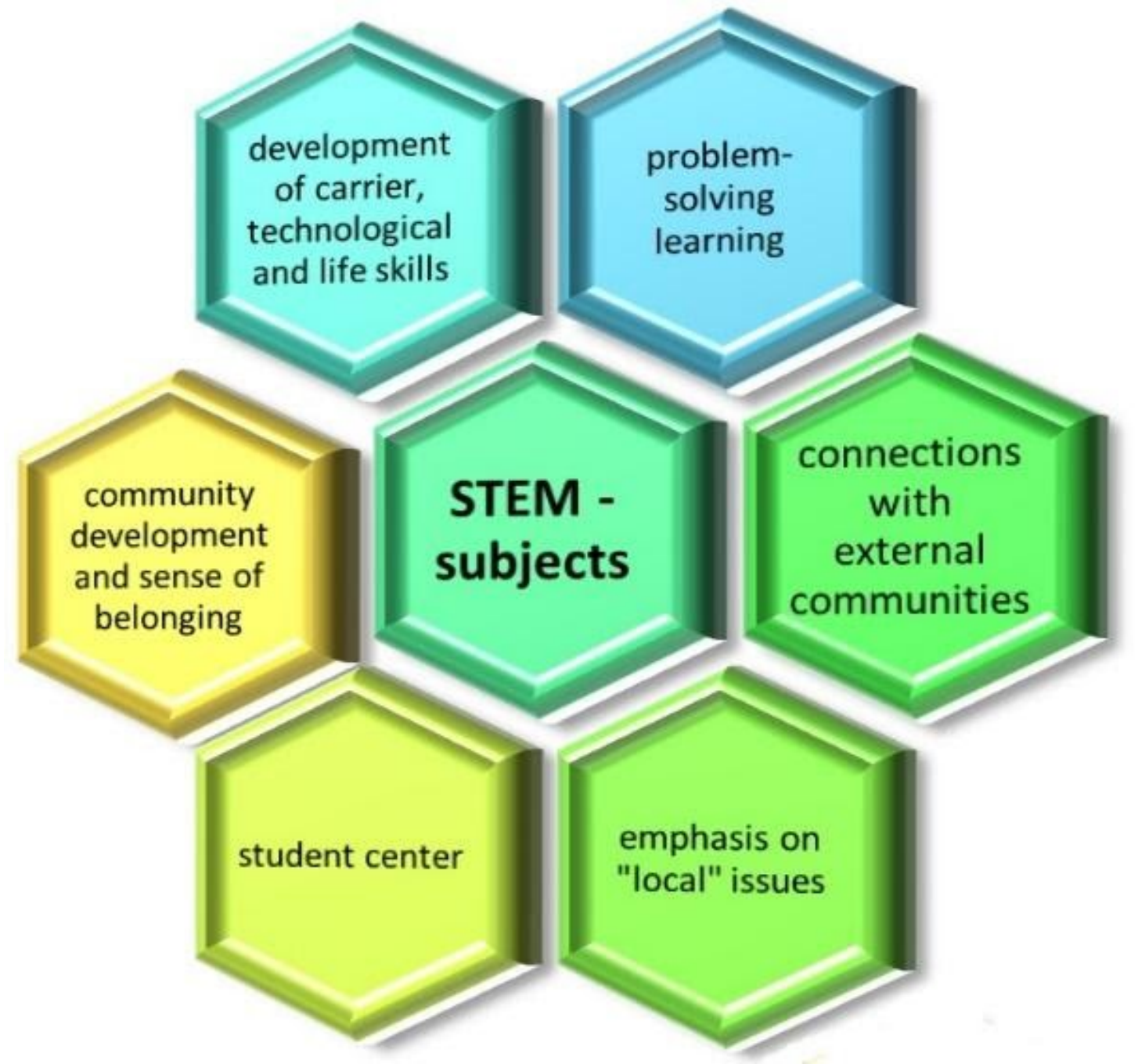

Fig 1. STEM - subjects

Using such methods as observation and collection of facts, testing, simulating, analysis and design, system approach - we make students try to use critical and creative thinking, assess the situation and make conclusions, work in a team and keep one's ears open to different points of view to obtain the coordinated decision.

The purpose of the article is to summarize the modern approaches to STEM education for future ship engineers: the problem-based learning activities, not standard or typical designs and problems, the integration of STEM subjects, the introduction of innovation to teaching methods in 
relation to each subject, the multidisciplinary approach to STEM education that implies the integrative environment for teaching STEM subjects.

\section{Results and discussion}

To use the STEM in training of future ship engineers the model of training of "English for special purpose" with the help of distance STEM was developed at Kherson State Maritime Academy (KSMA). English for special purpose is one of the professional disciplines studied at ship engineering department. It includes mainly the dictionary of technical term needed to work in engine room. The studying of English for special purpose of ship engineers is different from another maritime specialties only in content of this discipline. The process of future maritime professionals studying is also dictated by the need of real sea practice on the ship.

To create the model of distance STEM education, use in the training of future ship engineers three stages of its development were taken. At the initial stage of the pedagogical model creation the basic principles of modeling were taken into account: clarity, clearness and objectiveness.

While determination of the structure of the model we went through the following stages: definition of purpose; description of the content of the model; list of methodological approaches, principles, traditional and innovative methods of teaching, description of selected pedagogical conditions, determination of the main result, experimental verification of the model.

Thus, the model includes pedagogical conditions of ship engineers' training, methodological approaches used while training, principles and methods using which proper training of cadets is carried out.

The model included different blocks and as a result formed English speaking competency on a high or sufficient level. The structure of model can be seen in table 1 .

Table 1

The Model of Distance STEM Education Use in the Training of Future Seafarers

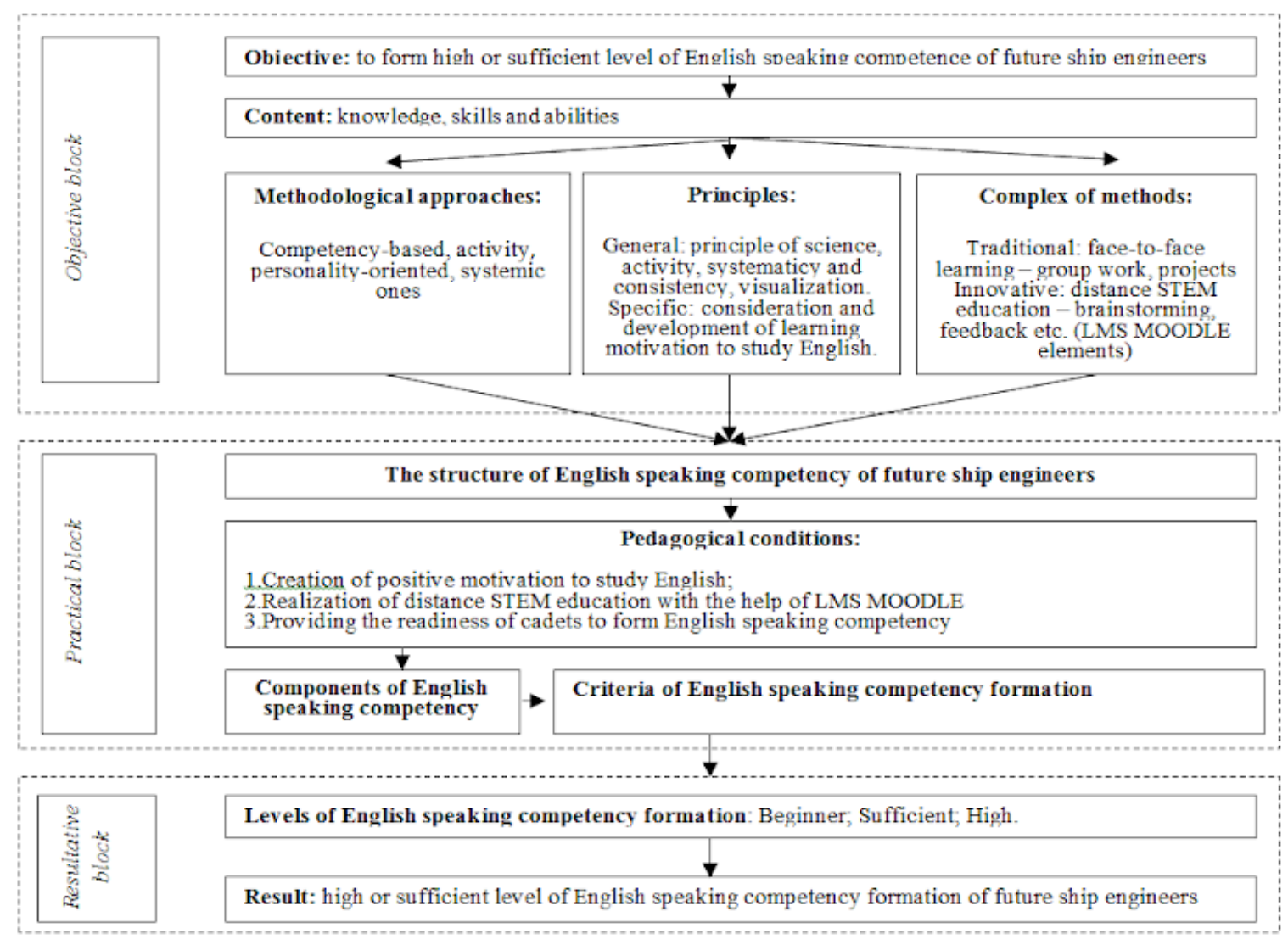


To describe the model of English for special purpose formation of future ship engineers it should be said that it consists of three blocks (objective, practical and resultative one). The first block includes the objective, content, methodological approaches, principles and methods of study [9-11]. Practical block includes the structure of English speaking competence, pedagogical condition applied during the research, as a result - components of English speaking competency and the criteria of its formation. Resultative block includes levels of English speaking competency formation and result of research.

According to Poyraz \& Kumtepe to apply the model elements of STEM education were applied into e-courses of LMS MOODLE which is the main source of education during distance learning. The e-course for future ship engineers was created at KSMA. Distance lessons are conducted according to lesson plans [12-14]. The example of part of lesson plan can be found in table 2 [15-16].

Table 2

Lesson plan outline

\begin{tabular}{|l|ll|}
\hline Date: 17.03 .2020 & Group: $211-212 \quad$ abridged \\
Module: Measuring Electricity & programme & \\
Topic: Basics of Electricity & & \\
Objective: you will be able to explain Ohm's Law. & & \\
Vocabulary: ammeter, voltmeter, ohmmeter, multimeter, & & \\
wattmeter. & & \\
Grammar: Type 0 Conditionals & & \\
\hline
\end{tabular}

\begin{tabular}{|c|c|c|c|c|c|}
\hline № & Stages & Activities & Interaction & Time & $\begin{array}{l}\text { Teaching } \\
\text { aids }\end{array}$ \\
\hline 1. & Brainstorm & $\begin{array}{l}\text { Cadet's report } \\
\text { T: In pairs, discuss what electric } \\
\text { meters you know, which of them you } \\
\text { have ever seen and used. } \\
\text { Comment on the picture. } \\
\text { The topic of our lesson is } \\
\text { "Measuring Electricity" } \\
\text { By the end of the lesson you will be } \\
\text { able to explain destination of some } \\
\text { electrical measuring devices and } \\
\text { rules of their use: ammeter, } \\
\text { voltmeter, ohmmeter, multimeter and } \\
\text { wattmeter. } \\
\text { Checking home task }\end{array}$ & T-S-S & $6 \mathrm{~min}$. & picture \\
\hline 2. & Investigate & $\begin{array}{l}\text { T: What is the proper use of the } \\
\text { words "electric" and "electrical"? } \\
\text { Give your ideas } \\
\text { Give your comments on the } \\
\text { examples. } \\
\text { T: With this distinction in mind, sort } \\
\text { the given words into two columns. } \\
\text { T: Correct your variants. }\end{array}$ & $\begin{array}{l}\text { S-S } \\
\text { S-Gr } \\
\text { PW } \\
\text { S-S-S } \\
\text { S-Gr }\end{array}$ & 14 min. & \\
\hline
\end{tabular}


The examples of the activities according to lesson plan are provided in figures 2-3.

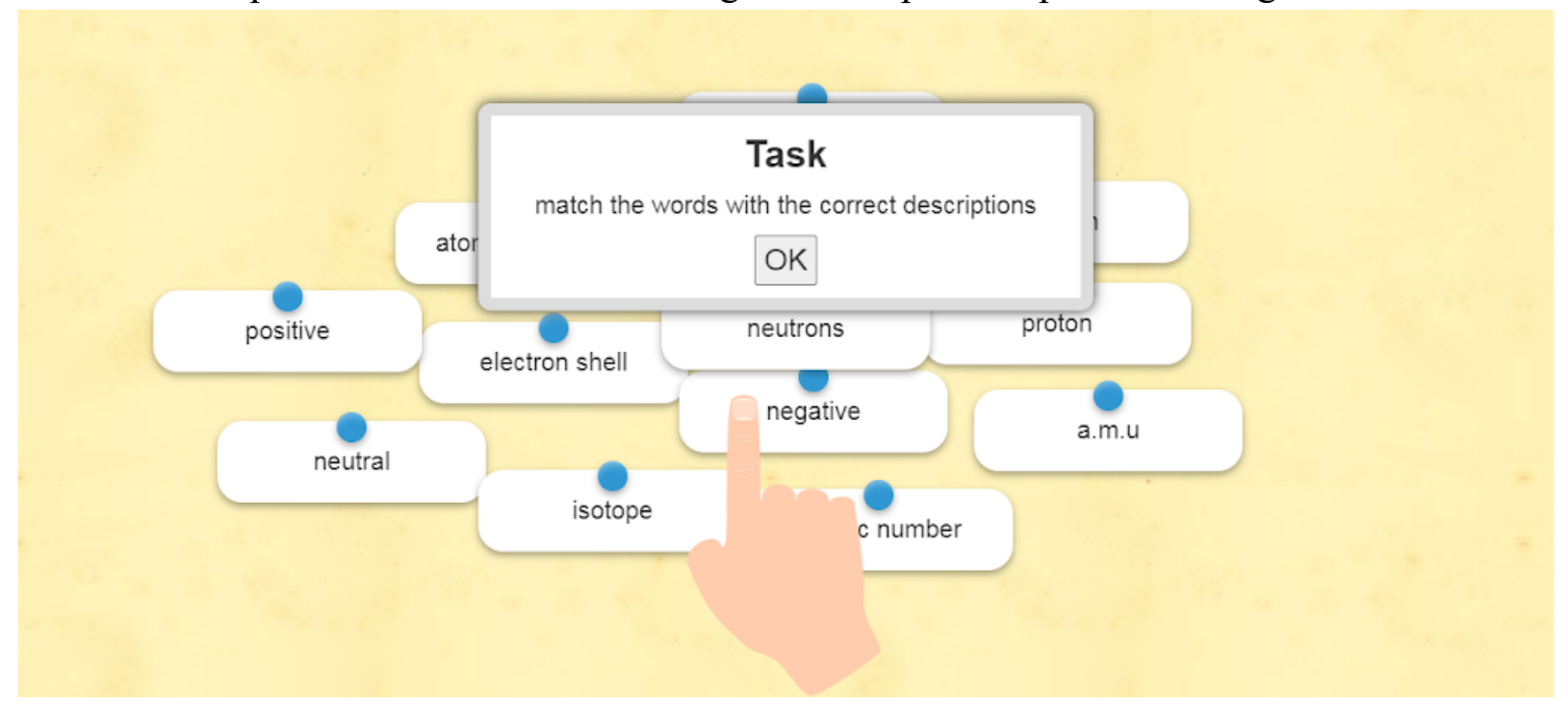

Fig. 2. Example of Apply stage activity on LMS MOODLE

\section{Measuring Electricity: Project}

Make up a project on one measuring electricity device

Plan

- Name

-Definition

-Purpose

-Picture

-Advantages and Disadvantages

Separate groups All participants

Grading summary

Hidden from students

Participants

Submitted

Needs grading

Fig. 3. Example of Create stage activity on LMS MOODLE

\section{Conclusions}

In Ukraine today, one can observe some stratification, which the STEAM approach is designed to combat: some teachers, curricula and entire educational institutions focus on technical disciplines and their applicability (STEM). At the same time, schoolchildren and students themselves may be interested in creativity, but their aspirations do not find a response from teachers. Creativity is rarely added to the curriculum along with technical disciplines - individual 
humanities in schools with a technical bias are almost "optional": an assessment in philosophy for a tech student does not even play an important role psychologically.

On the other hand, if we take the experience of the same company Apple, then it emphasized technology, usability, infrastructure and - not least! - on the design of their products, determining for at least a decade trends in mobile technologies that have spawned a whole multibillion-dollar industry.

Then graduates will be able to use their skills successfully, and will compete with graduates of the world's leading educational institutions in the ability not only to acquire knowledge independently, but also to use them competently in the conditions of modern achievements of science and technology.

STEM student will get more autonomy. In such a way, they will become self-reliant, and be responsible for their decisions. In the engineering solution, the technical potential is used, and the individual abilities of each student are taken into account when he has a choice of the direction of creative thinking and the pace of activity.

Of course, the ways to implement STEM training are not limited to these opportunities, their prospects are much wider than those described, and today, each teacher, his skill and personal interest depends on how ready the society is now for the widespread introduction of innovative technologies.

Here we need to mention another perspective of STEM programs - the use of problem-based learning. This approach has proven itself in teaching natural sciences, and in the implementation of STEM approaches, solving problematic situations, finding the right answers, overcoming obstacles to a planned solution can be implemented in the best way. An important point here is the formation in students of a special style of mental activity, research activity and independence, for example, in the created model of an environmentally friendly house, the natural lighting control system may not work, to eliminate this problem, you need to find the cause of the problem, develop a sequence of steps to solve it, use the knowledge of mathematics, physics, the characteristics of natural materials to solve it.

Critical thinking skills and in-depth scientific knowledge gained through STEM education allow a student to grow as an innovator - the engine of human development. It is impossible to overestimate the prospect of using information technology in the implementation of STEM programs.

Today, graduates of educational institutions that actively use information technology in medicine, construction, chemistry, physics, biotechnology and other fields of science are becoming more and more in demand. In STEM classes, an integral part of students 'work is the use of computer programs for designing calculations, and in most projects, an electronic prototype is created before constructing a material model.

Using the appropriate software available today for every middle-level student, it is possible to test the technical properties and effectiveness of the final product on an electronic prototype. For example, it is possible to verify that the characteristics of a deep-water research station correspond to actual conditions using data on the aquatic environment, such as density, temperature, pressure, and kinetics.

1. Gordon, B. (2007). H. R. 2272 - 110th Congress (2007-2008): America Creating Opportunities to Meaningfully Promote Excellence in Technology, Education, and Science Act. Retrieved May 25, 2020, from https://www.congress.gov/bill/110th-congress/house-bill/02272

2. Sherman, M. (2014). Research Of Influence Of Computer Training Of Future Lawyers On Indicators Of Academic Achievement. Information Technologies in Education, 19, 34-44. doi:10.14308/ite000482 
3. Yurzhenko, A. (2019). An E-Course Based On The LMS MOODLE To Teach "Maritime English For Professional Purpose". Information Technologies and Learning Tools, 71(3), 92. doi:10.33407/itlt.v71i3.2512

4. Poyraz, G. T., \& Kumtepe, E. G. (2019). An Example of STEM Education in Turkey and Distance Education for Sustainable STEM Learning. Journal of Qualitative Research in Education, 7(4), 1-20. doi:10.14689/issn.2148-2624.1.7c.4s.2m

5. Bykov,V. Yu.(2011). Cloud technologies, ICT outsourcing and new functions of ICT units of educational and scientific institutions. Information technologies in education, 10, 8-23.

6. Lapinsky,V. V., Pylypchuk, A. Yu. \& Shyshkina, M. P. (2010). Means of Information and Communication Technologies of the Single Information Space of the Ukrainian Education System (monograph). Kyiv: Pedahohichna dumka.

7. Demyanenko, V. M. \& Shyshkina, M. P. (2011). Methodical recommendations on the evaluation of the quality of electronic resources and resources in the educational process. Information Technologies and Learning Tools, 6 (26). Retireved from https://journal.iitta.gov.ua/index.php/itlt/article/view/589/462.

8. Lavrentieva, G. P. (2011). Methodical recommendations on the selection and use of electronic teaching aids in general educational institutions. Information Technologies and Learning Tools, 4(24). Retrieved from http://journal.iitta.gov.ua/index.php/itlt/issue/view/547/438.

9. Kochler, H. (2010). The Meaning and Challenges of Education in the 21st Century (lecture from 9.11.2010). Retrieved from http://www.hanskoechler.com/Koechler-Education-NCLIE-UNESCO-Paris-Nov2010-V2.pdf.

10. Bespalko, V. P. (2008). Education and training with the participation of computers (pedagogy of the third millennium). Moscow: Publishing house MPSI. Retrieved from https://eusi.ru/lib/bespalko_obrasovanie/index.php.

11. Macejko, O. V. (2012). Theoretical foundations of use of information technologies at the professional and technical level. Modern information technologies and innovative teaching methods in the training of specialists: methodology, theory, experience, problems, 32, 184-189. Retrieved from http://nbuv.gov.ua/UJRN/Sitimn_2012_32_39.

12. Lytvyn, A. V. (2010). Pedagogical conditions of informatization of the educational process in the vocational educational institution of the building profile. Pedagogy and psychology of vocational education, 5, 65-78. Retrieved from http://lib.iitta.gov.ua/5254/1/St_Литвин_Педагогічні_умови_інформ.pdf.

13. Morze, N. V. (2010). How to teach teachers how computer technology ceases to be a miracle in the classroom? Computer at school and family, 6, 10-14. Retrieved from http://nbuv.gov.ua/UJRN/komp_2010_6 4.

14. Chaykovskaya, E. A. (2001). Innovative Information Technologies in Education. The VIII International Conference "Libraries and associations in a changing world: new technologies and new forms of cooperation", 9-17 June 2001. Retrieved from http://www.gpntb.ru/win/inter-events/crimea2001../tom/tom3/Doc13.html.

15. Spirin, O. M. (2013). Criteria and indicators of the quality of information and communication technologies of training. Information Technologies and Learning Tools, 1(33). Retrieved from https://journal.iitta.gov.ua/index.php/itlt/article/viewFile/788/594. 
16. Zhaldak, M. (2011). Teacher training system for the use of information and communication technologies in the educational process. Informatics and information technologies in educational institutions, 4-5, 76-82. Retrieved from http://lib.iitta.gov.ua/869/1/Система_підготовки_вчителя.pdf.

Кононова О. Ю. ${ }^{1}$, Юрженко А. Ю. ${ }^{2}$

${ }^{1}$ Морський коледж Херсонської державної морської академії, Херсон, Україна

${ }^{2}$ Херсонська державна морська академія, Херсон, Україна ЗАЛУЧЕННЯ МАЙБУТНІХ СУДНОВИХ МЕХАНІКІВ ДО ДИСТАНЦІЙНОГО STЕМ НАВЧАННЯ

Дослідження узагальнює сучасні підходи до STEM-навчання для майбутніх суднових механіків: проблемно-орієнтоване навчання, нестандартні або типові конструкції та проблеми, інтеграція предметів STEM, упровадження інновацій у методи навчання стосовно кожного предмета, багатопрофільний підхід до STEM-освіти, що передбачає інтегративне середовище для викладання предметів STEM. Підкреслюється, що в епоху індустріалізації грамотність та трудові навички були важливими, але в постіндустріальну епоху на перший план вийшли технологічні аспекти розвитку молоді. Також було визначено, що, пробуджуючи творчий підхід, інтерес до всебічного сприйняття предмета дослідження, критичного мислення, учителі STEM дають студентам не просто знання - вони також дають їм навички, зацікавленість до знань і роботи, бажання занурюватися в саморозвиток, любити сам процес навчання. У дослідженні представлено змістовні та структурні характеристики цілей STEM, приблизні результати навчання, зміст, підсумкове оцінювання, зони фокусування (вирішення проблемних ситуацій), методи проєктування технологічної навчальної програми, передбачені методами STEM. У дослідженні описано практичний досвід залучення вчителів до створення STEM-проєктів для суднових інженерів у дистанційній STEM-освіті. Зроблено висновок, що неможливо переоцінити перспективу використання інформаційних технологій у процесі реалізації програм STEM. Також наголошено, що випускники закладів освіти, які активно використовують інформаційні технології в медицині, будівництві, хімії, фізиці, біотехнологіях та інших галузях науки, стають усе більш затребуваними.

Ключові слова: STEM-навчання, судномеханіки, MOODLE, креативне вирішення завдань, інформаційна технологія.

Стаття надійшла до редакції 21.11.2020

The article was received 21 November 2020 